\title{
Correction to: Bribes, market power and access to credit: evidence from cross-country firm-level data
}

\author{
Le Thanh Ha ${ }^{1}$ D $\cdot$ Dao Hanh Le ${ }^{1} \cdot$ Nguyen Ngoc Mai $^{1}$
}

Published online: 6 November 2021

(c) Springer-Verlag GmbH Germany, part of Springer Nature 2021

\section{Correction to: International Review of Economics https://doi.org/10.1007/s12232-021-00381-1}

In the original publication of the article, the information about the funding was provided by the author in the Acknowledgements section by mistake, but the article did not belong to any project, and did not receive any financial support. So, the funding information was removed.

The original article has been corrected.

Publisher's Note Springer Nature remains neutral with regard to jurisdictional claims in published maps and institutional affiliations.

The original article can be found online at https://doi.org/10.1007/s12232-021-00381-1.

Le Thanh Ha

halethanh.kt@gmail.com

Dao Hanh Le

hanhle20111999@gmail.com

Nguyen Ngoc Mai

mainguyenngoc2099@gmail.com

1 National Economics University, Hanoi, Vietnam 